\title{
Instytucja sędziego śledczego w II Rzeczypospolitej
}

I. W ostatnich latach toczy się w Polsce dyskusja na temat modelu postępowania karnego, zwłaszcza jego fazy przygotowawczej. Jej przedmiotem są między innymi propozycje zmian zmierzających do stworzenia szerszego zakresu kontroli sądowej nad postępowaniem przygotowawczym. Rozważa się możliwość i zasadność wprowadzenia, a raczej przywrócenia, istniejącej już wcześniej w Polsce, instytucji sędziego śledczego w takiej czy innej postaci. Nie chodzi zapewne o powrót do XIX-wiecznej koncepcji sędziego prowadzącego śledztwo, lecz raczej o koncepcję sądu czy sędziego do spraw postępowania przygotowawczego, powołanego do wykonywania i kontrolowania czynności podejmowanych w jego trakcie. Dyskusji nad zmianami modelu postępowania przygotowawczego, a zwłaszcza przywróceniem instytucji sędziego śledczego, towarzyszy też ożywienie w fachowym piśmiennictwie. W ostatnim okresie ukazał się szereg interesujących publikacji na ten temat ${ }^{1}$.

Wydaje się więc zasadne przypomnienie modelu tej instytucji od momentu pojawienia się jej na ziemiach polskich jeszcze pod zaborami aż do chwili likwidacji w czasach stalinowskich. Najważniejszym jednak punktem odniesienia do czasów współczesnych jest okres dwudziestolecia międzywojennego, zwłaszcza że za sprawą zmieniającego się ustawodawstwa, instytucja ta

${ }^{1}$ Zob. K. Eichstaedt, Rola sądu w postępowaniu przygotowawczym a instytucja sędziego śledczego, Warszawa 2009; C. Kulesza, Sędzia śledczy w modelu postępowania przygotowawczego na tle prawnoporównawczym, Białystok 1991; idem, Sędzia śledczy w wspótczesny proces karny (na tle prawnoporównawczym), „Państwo i Prawo” 2008, z. 7, s. 20 i n.; P. Kruszyński, M. Warchoł, Pozycja sędziego śledczego na tle modeli postępowania przygotowawczego (cz. 1), „Palestra” 2008, $\mathrm{Nr}$ 3-4, s. 49 i n. oraz (cz. 2) Nr 5-6, s. 44 i n.; J. Tylman, Uwagi o modelu postępowania przygotowawczego, [w:] Węzłowe problemy procesu karnego, pod red. P. Hofmańskiego, Warszawa 2010, s. 91 i n.; T. Grzegorczyk, Kilka refleksji na temat sugestii wprowadzenia instytucji sędziego śledczego, [w:] op. cit. s. 105 i n.; P. Kruszyński, M. Warchoł, Sędzia śledczy. Argumenty za i przeciw, [w:] op. cit., s. 115 i n.; C. Kulesza, Sędzia śledczy na tle zmian europejskich modeli postępowania przygotowawczego, [w:] op. cit., s. 124 i n.; R.A. Stefański, Krytycznie o obecnym modelu postepowania przygotowawczego, [w:] op. cit., s. 146 i n.; M. Kościelniak-Marszał, Sędzia śledczy w ujęciu prawno-historycznym, [w:], op. cit., s. $167 \mathrm{i}$. 
ewoluowała, przybierając różne formy. Dobrze więc przyjrzeć się bliżej tym rozwiązaniom, ale także - co jest nie mniej interesujące - przedstawić poglądy ówczesnych prawników - teoretyków i praktyków - na temat celowości jej istnienia, zakresu zadań oraz relacji z innymi organami uczestniczącymi w postępowaniu przygotowawczym, czyli z prokuraturą i policją państwową.

Najpierw zostały przedstawione regulacje prawne dotyczące sędziego śledczego obowiązujące w Polsce okresu międzywojennego. Są to, zarówno obowiązujące początkowo i różne w odniesieniu do poszczególnych obszarów państwa przepisy pozaborcze, jak i wprowadzone w drugiej dekadzie okresu międzywojennego jednolite regulacje polskiego prawodawcy. $Z$ uwagi na to, że problematyka dotycząca sędziego śledczego nie jest jednorodna, są to z jednej strony uregulowania zawarte w procedurze karnej, z drugiej - przepisy dotyczące ustroju sądownictwa. Pierwsze - określają pozycję procesową sędziego śledczego, w szczególności zakres jego kompetencji w postępowaniu przygotowawczym oraz stosunek do innych organów w nim uczestniczących; drugie - regulują status sędziego: sposób powoływania, prawa i obowiązki sędziowskie, zasady wykonywania zawodu. Dopiero analiza obydwu tych elementów daje pełny obraz instytucji. Następnie zaprezentowano najczęściej wyrażane poglądy na istotę, znaczenie i pozycję sędziego śledczego.

II. Instytucja sędziego śledczego pojawiła się $\mathrm{W}$ europejskim procesie karnym w XIX w. Jej modelowy kształt został stworzony - jak wiadomo - we Francji napoleońskiej na mocy kodeksu postępowania karnego (d'instruction criminelle) z 1808 r., ale prototyp był znacznie wcześniejszy, bo pochodził z dekretu Franciszka I z 1522 r. Znany wówczas jako lieutenant criminel był powołany do prowadzenia śledztwa i równocześnie - w asyście asesorów - do wyrokowania. Napoleoński kodeks postępowania karnego, dzieląc to postępowanie na dwie fazy: wstępną i główną, pierwszą z nich pozostawił w rękach prokuratora - uprawnionego do ścigania przestępstw i wszczynania śledztwa oraz sędziego śledczego, któremu po raz pierwszy powierzono prowadzenie śledztwa - obligatoryjnego w sprawach o zbrodnie oraz fakultatywnego w sprawach o występki ${ }^{2}$. Ideą przyświecającą twórcom tej instytucji było zapewnienie solidnego i należycie uzasadnionego oskarżenia, a tym samym zapobieżenie lekkomyślnemu wszczynaniu procesu. Zadaniem sędziego śledczego miało być nie tylko zebranie dowodów przestępstwa obciążających podejrzanego, dających podstawę do sporządzenia aktu oskarżenia, ale też o ile przebieg śledztwa na to wskazywał - ochrona osób, które czynów przestępczych nie popełniły. Sędzia śledczy dzięki swojej niezależności miał być lepszym gwarantem ochrony praw jednostki w procesie karnym niż zależny

${ }^{2}$ S. Waltoś, Sędzia śledczy - rys historyczny, [w:] Nowy model postępowania przygotowawczego - sędzia śledczy. Konferencja. Warszawa 22 marca 2010 r., Warszawa 2010, s. 16-17. 
i odwoływalny prokurator ${ }^{3}$. Stopniowo model ten przyjmował się, choć nieraz z pewnymi modyfikacjami, w większości krajów europejskich. Na ziemiach polskich instytucja sędziego śledczego pojawiła się w drugiej połowie XIX w. i to niemal jednocześnie we wszystkich trzech zaborach: w austriackim w 1873 r., w rosyjskim w 1876 r. i pruskim w 1877 r., oczywiście za sprawą ustawodawstwa państw zaborczych, choć niewiele brakowało, a zawitałaby nawet znacznie wcześniej, bo w czasach Księstwa Warszawskiego, kiedy to minister Feliks Łubieński czynił starania, ostatecznie bezskuteczne, o wprowadzenie tam procedury napoleońskiej.

1. W zaborze austriackim skrystalizowaną już formę instytucji przyniosła austriacka ustawa o postępowaniu karnym z dnia 23 maja 1873 r. $^{4}$ Obowiązywała ona na ziemiach polskich nie tylko do momentu odzyskania niepodległości, ale także w pierwszej dekadzie istnienia II Rzeczypospolitej aż do chwili wejścia w życie z dniem 1 lipca 1929 r. jednolitego kodeksu postępowania karnego. Przez ten ponadpięćdziesięcioletni okres doznawała licznych zmian i uzupełnień, które najpierw były dziełem ustawodawcy austriackiego, a następnie polskiego. Zmiany te jednak nie dotyczyły instytucji sędziego śledczego, która zachowała do końca swój pierwotny, stworzony przez ustawodawcę austriackiego, kształt.

Sędziowie śledczy działali wyłącznie w sądach okręgowych (w czasach monarchii austro-węgierskiej zwanych trybunałami pierwszej instancji). Do pełnienia tej funkcji powoływał ich prezes spośród sędziów tego sądu w liczbie od jednego do kilku ( $\$ 11$ austriackiego kpk). Ich status był analogiczny do statusu pozostałych sędziów orzekających w sądzie okręgowym ${ }^{5}$. Choć sędziowie śledczy nie byli powoływani w innych sądach, ani powiatowych, ani apelacyjnych (zwanych wcześniej trybunałami drugiej instancji) czy tym bardziej w Sądzie Najwyższym, to jednak podobne uprawnienia procesowe nakładano w pewnych okolicznościach również na sąd powiatowy.

Rola sędziego śledczego była związana przede wszystkim z postępowaniem przygotowawczym, które przybierało formę dochodzenia przygotowawczego lub śledztwa wstępnego. Dochodzenie przygotowawcze obejmowało wstępne czynności sądowe (np. przesłuchania osób, oględziny miejsca zdarzenia) wszczynane na wniosek prokuratora lub - w wyjątkowych okolicznościach - również bez tego wniosku (§ 88 i 89 austriackiego kpk). Prokurator mógł żądać ich przeprowadzenia od sędziego śledczego, sądu powiatowego lub policji. W sytuacji nie cierpiącej zwłoki sędzia śledczy, a zwłaszcza sąd

${ }^{3}$ W. Nestorowicz, Stanowisko sędziego śledczego u nas i na zachodzie, „Głos Sądownictwa” 1932, Nr 3, s. 206-207.

4 „Reichsgesetzblatt für die im Reichrat(h)e vertretenen Königreiche und Länder” 1873, Nr 119.

${ }^{5}$ Zob. M. Materniak-Pawłowska, Ustrój sadownictwa powszechnego w II Rzeczypospolitej, Poznań 2003, s. 117-121. 
powiatowy, w którego siedzibie nie było prokuratora, miały prawo do podjęcia samodzielnie czynności sądowych wchodzących w zakres postępowania przygotowawczego, o czym byli jednak zobowiązani prokuratora zawiadomić. Sędzia - zarówno śledczy, jak i powiatowy - wykonujący czynności w drodze postępowania przygotowawczego wchodzili w zakres uprawnień przysługujący sędziom prowadzącym śledztwo wstępne ( 88 austriackiego kpk). Po ukończeniu dochodzenia przygotowawczego sędzia miał obowiązek przesłać protokół z jego przeprowadzenia prokuratorowi, który z kolei podejmował decyzję co do dalszych losów postępowania: mógł zaniechać dalszych czynności, uznając, że brak jest do tego podstaw, mógł przekazać sprawę do śledztwa wstępnego lub wnieść od razu akt oskarżenia (§ 90 austriackiego kpk). Śledztwo wstępne mogło się rozpocząć tylko na wniosek prokuratora i toczyło się w sprawie konkretnego podejrzanego. Jego celem było ustalenie czy zachodzą wystarczające przesłanki do sporządzenia aktu oskarżenia lub zaniechania dalszego postępowania. Było ono obligatoryjne w sprawach o zbrodnie, podlegające sądowi przysięgłych, a także w sprawach prowadzonych przeciwko nieobecnym (§ 91 austriackiego kpk). Prowadzenie śledztwa wstępnego należało do sędziego śledczego, który był w tym zakresie samodzielny, niezwiązany dalszymi wnioskami prokuratury, lecz pozostawał pod nadzorem specjalnego 3-osobowego, powoływanego z początkiem każdego roku, wydziału danego sądu okręgowego zwanego Izbą Radną ( 12 austriackiego kpk). Instytucja ta wywodząca się z ustroju francuskiego, ale znacząco zmodyfikowana przez ustawodawcę austriackiego, zajmowała wobec sędziego śledczego stanowisko władzy przełożonej. Stanowisko to uwydatniało się w wielu kwestiach, na przykład: sędzia śledczy musiał zasięgać uchwały Izby Radnej w sprawie odrzucenie wniosku oskarżyciela o wdrożenie śledztwa wstępnego ( $\$ 92$ austriackiego kpk) lub zaniechania śledztwa wstępnego bez jego zgody ( 109 austriackiego kpk); sędzia śledczy miał obowiązek składania Izbie Radnej przynajmniej raz w miesiącu sprawozdania ze stanu prowadzonych śledztw wstępnych (§ 94 austriackiego kpk); przeciwko każdemu postanowieniu lub każdej zwłoce sędziego śledczego, niezadowolonej stronie służyło zażalenie do Izby Radnej (§ 113 austriackiego kpk) ${ }^{6}$. Izba Radna miała też prawo, w szczególnych przypadkach, przenieść prowadzenie śledztwa wstępnego w całości lub w części na sąd powiatowy znajdujący się w jej okręgu (§ 12 austriackiego kpk). W przypadku, gdy prawo przewidywało zażalenie na uchwałę Izby Radnej, rozstrzygał je właściwy sąd apelacyjny. Sam bieg śledztwa wstępnego oraz jego zakres zależały od planu ułożonego przez sędziego śledczego. Ustawa nie krępowała go tutaj żadnymi przepisami. Prowadził on śledztwo osobiście

${ }^{6}$ Zob. E. Krzymuski, Wykład procesu karnego ze stanowiska nauki i prawa obowiązujacego $w$ b. dzielnicy austriackiej oraz z uwzględnieniem ważniejszych różnic na innych ziemiach polskich, Kraków 1922, s. 48-49. 
i niezależnie od prokuratora, którego wnioski wiązały go tylko o tyle, że ich odrzucenie wymagało decyzji Izby Radnej. Ustawa o postępowaniu karnym wyraźnie zastrzegała, że żadnych czynności śledczych nie mógł wykonywać prokurator i to pod rygorem ich nieważności. Było natomiast możliwe powierzenie niektórych czynności, wchodzących w skład śledztwa, sądowi powiatowemu, zarówno znajdującemu się w okręgu, jak i poza okręgiem danego sądu okręgowego ( 93 austriackiego kpk). Ani oskarżyciel, ani obrońca nie mogli uczestniczyć w formalnym przesłuchaniu podejrzanego lub świadków. Mogli natomiast brać udział w takich czynnościach, jak oględziny miejsca zdarzenia, a nawet wskazywać przedmioty co do których należało w ich mniemaniu rozciągnąć czynności śledcze. W gestii sędziego śledczego pozostawały też, choć z pewnymi ograniczeniami, postanowienia dotyczące zakończenia śledztwa. Jego zupełnie niezależną decyzją było zamknięcie śledztwa w sytuacji, gdy uznawał, że dostarczyło ono już dostatecznej podstawy do sporządzenia przez prokuratora przeciwko podejrzanemu aktu oskarżenia ( $\S 111$ austriackiego kpk). Natomiast postanowienie o zaniechaniu śledztwa, w przypadku, gdy nie dostarczało ono podstaw do sporządzenia aktu oskarżenia, podejmował sędzia na wniosek lub za zgodą prokuratora, a w razie ich braku - za zgodą Izby Radnej ( $\$ 109$ austriackiego kpk).

2. W zaborze pruskim instytucja sędziego śledczego została uregulowana przede wszystkim w dwóch aktach prawnych z 1877 roku: w ustawie o ustroju sądownictwa ${ }^{7}$ oraz w ustawie postępowania karnego ${ }^{8}$. Obydwa akty prawne były później zmieniane i uzupełniane przez ustawodawcę niemieckiego, a po odzyskaniu przez Polskę niepodległości, obowiązując jeszcze przez dziesięć lat, przez ustawodawcę polskiego. Niektóre z tych zmian dotyczyły instytucji sędziego śledczego ${ }^{9}$.

Sędziowie śledczy działali również z zasady wyłącznie przy sądach okręgowych. W odróżnieniu od innych sędziów sądów powszechnych, którzy pochodzili z nominacji prezydenta Rzeczypospolitej, sędziowie śledczy (podobnie jak sędziowie pokoju) byli powoływani przez ministra sprawiedliwości i to na określony czas, tj. jeden rok administracyjny ( $\$ 60$ niemieckiej ustawy o ustroju sądownictwa), przy czym na mocy zarządzenia prezesa sądu mogli jeszcze po upływie tego okresu prowadzić rozpoczęte wcześniej śledztwa (§ 64 niemieckiej ustawy o ustroju sądownictwa). Sędziowie śledczy byli członkami sądu okręgowego, a ich status nie odbiegał od statusu pozostałych

${ }^{7}$ Ustawa o ustroju sądownictwa (,Reichs-Gesetzblatt” 1877, Nr 4, s. 41-80).

${ }^{8}$ Ustawa postępowania karnego (,Reichs-Gesetzblatt” 1877).

${ }^{9}$ M.in.: rozporządzenie o organizacji sądów w b. dzielnicy pruskiej („Tygodnik Urzędowy” 1919, Nr 70, s. 410). Zob. Postępowanie karne obowiazujące na ziemiach zachodnich Rzeczypospolitej Polskiej. Zbiór ustaw i rozporządzeń dotyczących ustroju sądownictwa i procesu karnego z orzecznictwem Sądu Najwyższego. Oprac. J. Kałużniacki, R.A. Leżański, Warszawa-Poznań 1926, ss. 342. 
sędziów. W wyjątkowych przypadkach czynności należące do sędziego śledczego mogły być podejmowane również przez sędziów powiatowych lub sędziów pokoju.

Rola sędziego śledczego ograniczała się także przede wszystkim do prowadzenia śledztwa wstępnego - drugiej, obok dochodzenia wstępnego, fazy postępowania przygotowawczego. Było ono obligatoryjne tylko w sprawach o zbrodnie oraz w sprawach karnych, należących do właściwości sądu okręgowego, w których wniosek o wszczęcie złożyła prokuratura lub podejrzany, przedstawiający ważne powody uzasadniające taką potrzebę ( $\$ 176$ niemieckiej ustawy postępowania karnego). Samo ściganie przestępstw należało na tym obszarze przede wszystkim do niezależnej od sądów prokuratury, która miała obowiązek podejmowania działań w przypadku jakichkolwiek podejrzeń o popełnienie czynów podlegających karze (§ 152 niemieckiej ustawy postępowania karnego), ale także w pewnym zakresie do policji ( $\$ 156$ niemieckiej ustawy postępowania karnego). W trakcie dochodzenia wstępnego prokuratura miała obowiązek zbadać okoliczności sprawy i ostatecznie postanowić, czy wniesienie skargi publicznej wszczynającej śledztwo jest zasadne. W tym celu mogła ona żądać wyjaśnień od wszelkich władz publicznych, mogła też sama podejmować czynności ( $\mathrm{z}$ wyjątkiem przesłuchań pod przysięgą) lub zlecać ich wykonanie władzom, urzędnikom służby policyjnej (§ 159 niemieckiej ustawy postępowania karnego) i sądom ( 160 niemieckiej ustawy postępowania karnego). W przypadku tych ostatnich możliwe było zlecenie poszczególnych czynności nie tylko sędziom śledczym działającym w sądach okręgowych, ale także sędziom powiatowym czy sędziom pokoju. W uzasadnionych przypadkach, gdy zwłoka była zagrożeniem w sprawie, sędzia powiatowy lub pokoju mogli podjąć niezbędne czynności śledcze z urzędu (§ 163 niemieckiej ustawy postępowania karnego), sposób ich postępowania regulowały wówczas przepisy prawne dotyczące śledztwa. Po zakończeniu dochodzenia prokurator, w przypadku, gdy uznał, że są wystarczające podstawy do wniesienia skargi publicznej, albo wnosił o wszczęcie śledztwa wstępnego, albo wnosił bezpośrednio do sądu akt oskarżenia (z wyjątkiem spraw, w których śledztwo było obligatoryjne), w przeciwnym razie zarządzał umorzenie postępowania z urzędu ( $\$ 168$ niemieckiej ustawy postępowania karnego). Niemiecka procedura karna w odróżnieniu od austriackiej nie znała dochodzenia prowadzonego przez sąd, w całości prowadził je prokurator, choć mógł zlecić wykonanie niektórych czynności sędziom.

Podobnie jak w zaborze austriackim śledztwo mogło być wszczęte tylko na wniosek prokuratora ( $§ 152$ niemieckiej ustawy postępowania karnego). Wniosek taki mógł być odrzucony uchwałą sądu ${ }^{10}$, ale tylko z powodu nie-

${ }^{10}$ Zgodnie z $§ 72$ niemieckiej ustawy o ustroju sądownictwa wszystkie rozstrzygnięcia dotyczące śledztwa wstępnego, które według przepisów postępowania karnego wydawał sąd, należały do izb karnych tego sądu. W szczególności izby karne rozstrzygały o zażaleniach na zarządzenia 
właściwości sądu, niedopuszczalności ścigania karnego lub śledztwa w danej sprawie, albo w sytuacji, gdy czyn oznaczony we wniosku nie podpadał pod żaden przepis karny. Śledztwo toczyło się przeciwko konkretnemu podejrzanemu oraz w sprawie konkretnego zarzucanego mu czynu ( $\$ 177$ niemieckiej ustawy postępowania karnego), możliwe też było połączenie - na mocy uchwały sądu - spraw karnych pozostających ze sobą w związku ( 4 niemieckiej ustawy postępowania karnego). Śledztwo wstępne było prowadzone przez sędziego śledczego osobiście, jednak do wykonania poszczególnych czynności śledczych mógł on wzywać sędziów powiatowych, a na wniosek prokuratora uchwałą sądu okręgowego możliwe było nawet przekazanie prowadzenia śledztwa w całości sędziemu powiatowemu ( $\$ 183$ niemieckiej ustawy postępowania karnego). Czynności śledcze polegały między innymi na: przesłuchiwaniu podejrzanego, świadków i biegłych, dokonywaniu oględzin, wydawaniu nakazu aresztowania oraz za zgodą prokuratury jego uchylanie. Prokuratura miała prawo do wglądu w akta śledztwa, dowiadywania się o jego stanie oraz do składania wniosków takich, jakie uznała za stosowne (§ 194 niemieckiej ustawy postępowania karnego), jednak wykonanie tych wniosków nie było dla sędziego śledczego obligatoryjne, gdyż ostateczną instancją był sąd okręgowy. Sędzia śledczy decydował o zakończeniu śledztwa oraz przesyłał akta sprawy prokuratorowi, który mógł wnioskować o uzupełnienie śledztwa wstępnego lub wnieść akt oskarżenia do właściwego sądu. Wniosek o uzupełnienie śledztwa również nie wiązał bezwzględnie sędziego, gdyż ostateczne rozstrzygnięcie w tej sprawie należało do sądu okręgowego, a nie prokuratury. W sytuacji, gdy nie było podstaw do wniesienia aktu oskarżenia, sąd okręgowy wydawał postanowienie o umorzeniu postępowania (§ 196 niemieckiej ustawy postępowania karnego). Uprawnienia sądu okręgowego wynikały z $§ 204$ niemieckiej ustawy postępowania karnego, na mocy którego żadne wnioski prokuratury nie były dla sądu okręgowego wiążące ${ }^{11}$. Sędzia śledczy, który prowadził śledztwo, był z mocy ustawy wyłączony od wyrokowania $\mathrm{w}$ sprawie, czyli pozbawiony udziału w dalszych stadiach postępowania ( $\$ 23$ niemieckiej ustawy postępowania karnego). W byłym zaborze pruskim z pewnością nie występował przerost uprawnień prokuratorskich względem uprawnień sędziego śledczego.

3. Na obszarze zaboru rosyjskiego instytucja sędziego śledczego została wprowadzona na podstawie reformy sądowej z 1864 r., która z pewnymi zmianami zaczęła obowiązywać w Królestwie Polskim w 1876 r. Częścią tej reformy była ustawa o postępowaniu karnym oraz ustawa o organizacji sądownictwa. W 1917 r. na obszarze Królestwa Polskiego, czyli dwóch

sędziego śledczego, a także na zarządzenia - wykonujących czynności śledcze - sędziego powiatowego i sędziego pokoju.

${ }^{11}$ Zob. W. Nestorowicz, Stanowisko sędziego śledczego u nas i na zachodzie, „Głos Sądownictwa" 1932, Nr 3, s. 147. 
ówczesnych Generał-Gubernatorstw: Warszawskiego i Lubelskiego, dzięki staraniom Departamentu Sprawiedliwości Tymczasowej Rady Stanu, dotychczasowa struktura sądownictwa rosyjskiego została zastąpiona nową, w postaci sądownictwa Królewsko-Polskiego ${ }^{12}$. Równocześnie dokonano też zmian i uzupełnień w rosyjskiej procedurze karnej, wydając do niej przepisy przechodnie ${ }^{13}$. Zmiany dotyczyły m.in. instytucji sędziego śledczego. Po odzyskaniu niepodległości regulacje, zarówno ustrojowe, jak i procesowe, poddawano kolejnym nowelizacjom, które w pewnym zakresie również odnosiły się do tej instytucji ${ }^{14}$.

W świetle przepisów rosyjskiej organizacji sądowej z 1864 r., wprowadzonej do Królestwa Polskiego w 1876 r., sędzia śledczy nazywany był inkwirentem sądowym (sudiebnyj sledowatiel) ${ }^{15}$. Działał przy sądzie okręgowym, ale nie był uważany za jego członka i nie brał udziału w zebraniach ogólnych sądu. Miał specjalnie wyznaczony okręg zwany cyrkułem śledczym. Ministrowi sprawiedliwości przysługiwało prawo wyznaczania jednego spośród działających przy danym sądzie okręgowym inkwirentów, do prowadzenia konkretnych śledztw w sprawach szczególnie ważnych (art. 79-80 rosyjskiej organizacji sądowej). Inkwirentami mogły być mianowane nie tylko osoby spełniające warunki konieczne do wykonywania zawodu sędziego, ale także aplikanci sądowi, jeśli wykazywali się „wystarczającą wiedzą i praktyką w prowadzeniu śledztw" (art. 205 rosyjskiej organizacji sądowej).

Pojęcie inkwirenta zniknęło w przepisach polskich konstruujących sądownictwo Królewsko-Polskie, zostało zastąpione przez pojęcie sędziego śledczego. Zmieniła się też nieco jego pozycja. Odtąd funkcjonował w sądzie okręgowym jako jeden z jego sędziów, choć jego status nie był dokładnie taki sam, jak pozostałych. Różnica dotyczyła m.in. uposażenia, sędziowie śledczy byli zaliczani do innej kategorii płac niż sędziowie sądu okręgowego. Mogli być jednak w razie potrzeby - decyzją prezesa sądu - powoływani do uzupełniania kompletów orzekających, nie mogąc jednak, co oczywiste, brać udziału w sądzeniu spraw, w których prowadzili wcześniej śledztwa ${ }^{16}$. Sę-

12 Przepisy tymczasowe o urządzeniu sądownictwa w Królestwie Polskim (Dziennik Urzędowy Departamentu Sprawiedliwości Tymczasowej Rady Stanu z dnia 19 sierpnia 1927 r., Nr 1, Dział I, poz. 1). Zob. na ten temat: M. Materniak-Pawłowska, Ustrój sądownictwa powszechnego w II Rzeczypospolitej, s. 73-75.

${ }^{13}$ Przepisy przechodnie do ustawy postępowania karnego (Dziennik Urzędowy Departamentu Sprawiedliwości Tymczasowej Rady Stanu z dnia 19 sierpnia 1927 r., Nr 1, Dział I, poz. 4).

${ }^{14}$ Szczególnie ważne zmiany wprowadziła ustawa z dnia 25 lutego $1921 \mathrm{w}$ przedmiocie zmian w ustawodawstwie karnym obowiązującym w byłym zaborze rosyjskim (Dz. U. 1921, Nr 30, poz. 169). Wprowadzono wówczas dochodzenie prokuratorskie.

${ }^{15}$ Art. 6 Organizacji sądowej, [w:] Ustawy sądowe obowiązujące w Guberniach Królestwa Polskiego na mocy najwyżej zatwierdzonego 19 lutego 1875 roku postanowienia o zastosowaniu ustaw sq̨dowych z 20 listopada 1864 roku do warszawskiego Okręgu Sądowego, T. I. Organizacja sądowa i ustawa notarialna, S. Petersburg 1875, s. 5.

${ }^{16}$ Art. 6 Przepisów tymczasowych o urządzeniu sądownictwa w Królestwie Polskim. 
dziowie śledczy wykonywali swoje obowiązki w wyznaczonych im rewirach (dawniejszych cyrkułach) i jedynie w pilnych sytuacjach mogli podejmować je także na obszarze innego rewiru. Rewiry ustanawiał i znosił minister sprawiedliwości, on też wydawał zarządzenia w sprawie zmiany ich granic.

Tutejsze przepisy regulowały też praktyczną, a właściwie techniczną stronę wykonywania obowiązków sędziego śledczego. W ich świetle stwierdzić można, że sędzia śledczy dysponował własną kancelarią, w której miał obowiązek urzędować w określonych przez siebie godzinach, a do pomocy mogli być oddelegowani do niego aplikanci sądowi, którzy w pewnych przypadkach dysponowali prawami i obowiązkami sędziego śledczego. Sędziowie śledczy musieli przedstawiać, zarówno sądowi okręgowemu, jak i prokuraturze dane o ruchu spraw w swoich rewirach ${ }^{17}$.

W zakresie postępowania przygotowawczego proces rosyjski charakteryzowały duża samodzielność sądu i mocno okrojona rola prokuratury, która często ograniczała się do nadzoru. Dochodzenia przeprowadzały władze policyjne, natomiast śledztwo - sędzia śledczy. Śledztwo było obligatoryjne w sprawach o zbrodnie i występki zagrożone karą więzienia ${ }^{18}$, a później tylko w sprawach o zbrodnie. Jego wszczęcie było możliwe, zarówno na wniosek prokuratora, jak i z własnej inicjatywy sędziego śledczego. W tym drugim przypadku mogło chodzić o sytuacje, w których sędzia śledczy sam powziął wiedzę o dokonaniu przestępstwa lub w przypadku zawiadomienia ze strony policji, urzędów czy samego sprawcy (art. 297 rosyjskiej procedury karnej). Sędzia śledczy mógł też samodzielnie uznać, że sprawa nie należy do właściwości danego sądu okręgowego i odesłać akta sprawy, ograniczając się jedynie do zawiadomienia prokuratora (art. 482 rosyjskiej procedury karnej). Nadzwyczajnym ograniczeniem władzy prokuratora w stosunku do sądu był brak możliwości umorzenia lub zawieszenia przez niego śledztwa z powodu jego bezzasadności lub innych powodów prawnych (art. 518 rosyjskiej procedury karnej). Miał on jedynie możliwość złożenia odpowiedniego wniosku do sądu okręgowego, a w razie, gdy sąd ten nie wyraził zgody na zaniechanie śledztwa, ostatecznie sprawę rozstrzygał sąd apelacyjny. Inaczej sprawa ta wyglądała w procesie austriacko-niemieckim, gdzie zgodnie z zasadą skargowości prawa, w razie odstąpienia prokuratora od skargi, następowało zaniechanie postępowania ${ }^{19}$.

W trakcie prowadzenia śledztwa sędzia śledczy miał dużą swobodę. W zakresie zbierania materiału dowodowego na uwagę zasługuje ciekawa kon-

${ }^{17}$ Art. 67-75 Tymczasowej Instrukcji Ogólnej dla sądów Królestwa Polskiego (Dziennik Urzędowy Departamentu Sprawiedliwości Tymczasowej Rady Stanu Królestwa Polskiego 1917, Nr 2, Dział III, poz. 4).

${ }^{18}$ Art. 8 Przepisów przechodnich do ustawy postępowania karnego.

${ }^{19}$ Zob. J. Makarewicz, Procedura karna dla Królestwa Polskiego, „Przegląd Prawa i Administracji”, 1918, s. 195. 
strukcja tzw. wywiadu środowiskowego, którego celem było „naświetlenie wartości moralnej” podejrzanego na podstawie przesłuchań świadków (art. 457-460 rosyjskiej procedury karnej). Prokurator sprawował wprawdzie stały nadzór nad śledztwem i mógł występować z rozmaitymi wnioskami, jednak nie naruszały one samodzielności sędziego śledczego. Sam natomiast był kontrolowany przez sąd okręgowy, ten zaś - przez sąd apelacyjny.

III. U schyłku lat dwudziestych dotychczasowa mozaika przepisów odnoszących się do ustroju sądownictwa oraz postępowania karnego została zastąpiona przez jednolite prawo. W stosunku do omawianej instytucji nastąpiły zasadnicze zmiany. Sędzia śledczy posiadający dotąd szerokie uprawnienia, a przede wszystkim w miarę samodzielne stanowisko w postępowaniu przygotowawczym, zaczął doznawać coraz większych ograniczeń.

Jednolite prawo o ustroju sądów powszechnych z 1928 r. znało nie tylko instytucję sędziego śledczego powoływanego jak dotąd w każdym sądzie okręgowym, ale też instytucję sędziego śledczego do spraw wyjątkowego znaczenia, powoływanego w sądzie apelacyjnym ${ }^{20}$. Instytucja sędziego śledczego do spraw wyjątkowego znaczenia została wprowadzona na obszarze całego państwa jeszcze w 1927 r., na mocy rozporządzenia prezydenta Rzeczypospolitej Polskiej ${ }^{21}$. Sędziowie śledczy do spraw wyjątkowego znaczenia byli ustanawiani w siedzibie sądu apelacyjnego i zakres ich działania obejmował cały ten okręg sądowy. Decyzja o zasadności ich powołania w danym sądzie apelacyjnym oraz liczbie należała do ministra sprawiedliwości. Byli mianowani przez prezydenta Rzeczypospolitej Polskiej na wniosek Rady Ministrów uchwalony z inicjatywy ministra sprawiedliwości (później - po zmianach wprowadzonych rozporządzeniem z 7 października 1932 r. - przez prezydenta Rzeczypospolitej Polskiej na wniosek ministra sprawiedliwości przedstawiony w porozumieniu z prezesem Rady Ministrów ${ }^{22}$ ) spośród osób, które przynajmniej przez pięć lat zajmowały stanowiska sędziowskie lub prokuratorskie. Ich zastępców wyznaczało zgromadzenie ogólne sądu apelacyjnego ${ }^{23}$. Pod względem stanowiska służbowego byli oni zrównani z pozostałymi sędziami sądu apelacyjnego. Celem powołania tej instytucji było umożliwienie skoncentrowania śledztwa w sprawach o cięższe przestępstwa,

${ }^{20}$ Prawo o ustroju sądów powszechnych z dnia 6 lutego 1928 r. (Dz. U. 1928, Nr 12, poz. 93).

${ }^{21}$ Rozporządzenie prezydenta Rzeczypospolitej z dnia 15 lipca 1927 r. o sędziach śledczych do spraw wyjątkowego znaczenia (Dz. U. 1927, Nr 69, poz. 611).

${ }^{22}$ Rozporządzenie prezydenta RP z dnia 7 października 1932 r., zmieniające niektóre przepisy Prawa o ustroju sądów powszechnych wprowadzało w stosunku do mianowania wszystkich sędziów jednolitą zasadę - mianowania ich przez prezydenta RP na wniosek ministra sprawiedliwości przedstawiony w porozumieniu z prezesem Rady Ministrów (Dz. U. 1932, Nr 86, poz. 734).

${ }^{23} \S 18$ pkt 3 Regulaminu ogólnego wewnętrznego urzędowania sądów apelacyjnych, okręgowych i grodzkich (Dz. U. 1928, Nr 104, poz. 934). 
popełnione w kilku okręgach, w ręku jednego sędziego i to bardziej doświadczonego, a także prowadzenie śledztwa przez sędziego „stojącego z dala od stosunków lokalnych"24. Sędzia śledczy do spraw wyjątkowego znaczenia podejmował prowadzenie śledztwa na skutek uchwały Sądu Najwyższego, powziętej na wniosek ministra sprawiedliwości jako naczelnego prokuratora, bądź na skutek uchwały Sądu Apelacyjnego powziętej na wniosek prokuratora przy Sądzie Apelacyjnym. Delegowany przez ministra sprawiedliwości prokurator, bądź prokurator przy Sądzie Apelacyjnym lub jego zastępca sprawowali nadzór prokuratorski nad wykonywanymi przez niego czynnościami, wyższą zaś instancję sądową stanowił sąd okręgowego działający w siedzibie sędziego śledczego do spraw wyjątkowego znaczenia.

Powołanie instytucji sędziów śledczych do spraw wyjątkowego znaczenia było w doktrynie krytykowane. Podnoszono między innymi, że jej utworzenie wzbudza przypuszczenia, iż w sądzie sprawy nie są traktowane z jednakową uwagą: jedne uważa się za ważniejsze i oddaje w ręce sędziów śledczych do spraw wyjątkowego znaczenia, inne - uznane za mniej ważne przekazuje „Zwykłym” sędziom śledczym. Za szczególne niedociągnięcie uznawano brak ustawowego sprecyzowania jakie sprawy miały być uznawane za sprawy o wyjątkowym znaczeniu, a to z kolei pociągało za sobą niepożądaną dowolność organów wymiaru sprawiedliwości ${ }^{25}$.

Sędziowie śledczy działający w sądach okręgowych byli sędziami okręgowymi. Prawo o ustroju sądów powszechnych z 1928 r. zniosło formalnie wszelkie różnice, jakie wcześniej występowały w obsadzie sądu okręgowego między sędziami. Dotychczasowi sędziowie śledczy, o ile mieli kwalifikacje sędziowskie (co przynajmniej w przypadku dawnego zaboru rosyjskiego nie było oczywiste), z dniem 1 stycznia 1929 r., kiedy prawo to weszło w życie, stawali się - z jego mocy - sędziami okręgowymi ${ }^{26}$. Musiały co do tego istnieć pewne wątpliwości, gdyż dodatkowo potwierdził to jeszcze później wyrok Sądu Najwyższego ${ }^{27}$. Tak więc ich pozycja w hierarchii stanowisk w sądownictwie została ugruntowana i to na wyższym niż dotąd poziomie. Mimo że formalnie status sędziów śledczych został zrównany ze statusem innych sędziów tego sądu, to pozostała odrębność polegająca na sprawowaniu odmiennej funkcji oraz na tym, że funkcja ta, polegająca na prowadzeniu czynności śledczych, była wyznaczana już przy nominacji, nie zaś przez zgromadzenie ogólne sądu

${ }^{24}$ Z nowego ustroju sądów powszechnych. Streszczenie i omówienie przepisów o ustroju sądów powszechnych ze szczególowym uwzględnieniem przepisów o sądach pracy przez dr J. Wz., Kraków 1929, s. 29-30.

${ }^{25}$ Ibidem, s. 118-119.

${ }^{26}$ Art. 280 § 2 Prawa o ustroju sądów powszechnych.

${ }^{27}$ Wyrok Sądu Najwyższego z dnia 12. 11.1929, [w:] Z. Nagórski, Prawo o ustroju sądów powszechnych $z$ dn. 6 lutego 1928 wedlug jednolitego tekstu $z$ dn. 5 listopada wraz z ustawami i rozporządzeniami związkowymi i wykonawczymi oraz orzecznictwem Sąu Najwyższego, Warszawa 1933, s. 9. 
okręgowego ${ }^{28}$. W praktyce jednak, wbrew regulacjom prawnym, choć zgodnie z interpretacją Ministerstwa Sprawiedliwości utrzymały się znacznie poważniejsze różnice ${ }^{29}$. Dotyczyły one przede wszystkim uposażenia, które formalnie miało przysługiwać sędziom śledczym według tej samej kategorii co sędziom okręgowym, a w rzeczywistości należało do kategorii niższej ${ }^{30}$.

Liczba sędziów śledczych dla każdego sądu okręgowego była określana przez ministra sprawiedliwości, on też mógł w razie potrzeby ustanowić dla nich siedziby poza siedzibą sądu okręgowego ${ }^{31}$. Formalnie również do ministra sprawiedliwości należało likwidowanie stanowisk sędziów śledczych. Jednak z uwagi na to, że sędzia śledczy był zarazem sędzią okręgowym, pozostawał on po zlikwidowaniu tego stanowiska nadal sędzią okręgowym (tego stanowiska minister sprawiedliwości nie był władny zlikwidować samodzielnie) i na mocy obowiązującego prawa miał przechodzić, zgodnie z uchwałą zgromadzenia ogólnego sądu, do jednego z jego wydziałów ${ }^{32}$. Było to formalne potwierdzenie zasady równorzędności sędziów śledczych z pozostałymi sędziami okręgowymi. Jednakże za sprawą interpretacji Ministerstwa Sprawiedliwości wykształciła się w tym zakresie inna praktyka ${ }^{33}$. Mianowicie przejście z kategorii sędziego śledczego do kategorii sędziego okręgowego i odwrotnie następowało w drodze każdorazowego wyboru kandydata przez ogólne zgromadzenie sądu i ponownego zamianowania go przez prezydenta Rzeczypospolitej Polskiej ${ }^{34}$. Rozporządzenie z 23 sierpnia 1932, stanowiące nowelę do Prawa o ustroju sądów powszechnych z 1928 r. wprowadziło - w razie zniesienia stanowiska sędziego śledczego w danej miejscowości - możliwość wyznaczenia osobie je sprawującej innej siedziby na obszarze danego sądu okręgowego, bez zmiany pełnionej funkcji ${ }^{35}$.

Wiele emocji budziła sprawa redukcji stanowisk sędziów śledczych, a zwłaszcza sposób jej przeprowadzania w praktyce. Z powodu braku szczegółowych przepisów wykonawczych, które wskazywałyby na kryteria decydujące o pozbawieniu danego sędziego funkcji śledczych, panowała w administracji sądowej zupełna dowolność. W niektórych przypadkach decydowało starszeń-

${ }^{28}$ Zob. A. Goldman, ,, Redukcja” sędziów śledczych w świetle przepisów prawa, „Gazeta Sądowa Warszawska" 1932, Nr 27, s. 375.

${ }^{29}$ Art. 57 § 3 Prawa o ustroju sądów powszechnych.

${ }^{30}$ N. Dąbrowicki, Jeszcze o uposażeniu sędziów okręgowych śledczych, „Głos Sądownictwa” 1931, Nr 5, s. 282-285.

${ }^{31}$ Art. 5 Prawa o ustroju sądów powszechnych.

$32 \S 17$ pkt 2 Regulaminu ogólnego wewnętrznego urzędowania sądów apelacyjnych, okręgowych i grodzkich (Dz. U. 1928, Nr 104, poz. 934). Zob. też W. Wiszniewski, O trybie zwijania stanowisk sędziów okręgowych śledczych, „Głos Sądownictwa” 1930, Nr 7/8, s. 443-445.

${ }^{33}$ Zob. W. Nestorowicz, Odmęty interpretacyjne, „Głos Sądownictwa” 1931, Nr 4, s. 218-221.

${ }^{34}$ Zob. W. Chmielarz, Wybieranie sędziów okręgowych śledczych na stanowisko sędziów okręgowych, „Głos Sądownictwa” 1929, Nr 4, s. 176-177.

${ }^{35}$ Rozporządzenie Prezydenta RP z dnia 23 sierpnia 1932 r., zmieniające niektóre przepisy Prawa o ustroju sądów powszechnych (Dz. U. 1932, Nr 73, poz. 661). 
stwo służbowe w ogóle, w innych starszeństwo służbowe w danym sądzie; przy czym w jednych starszeństwo to powodowało, że sędzia pozostawał przy swoich czynnościach, w innych - przeciwnie, starszeństwo, zwłaszcza gdy dawało prawo do emerytury, powodowało właśnie usunięcie z funkcji i pozostawienie przy niej osoby młodszej. Czasem główną rolę odgrywały jeszcze inne wzglę$\mathrm{dy}^{36}$.

Ogólna liczba sędziów śledczych wahała się od 142 (w 1936 r.) do 247 (w 1929 r.). W kolejnych latach wynosiła: w 1928 r.- 241 sędziów śledczych, w 1929 r. - 247, w 1930 r. - 231, w 1932 r. - 161, w 1934 r. - 210, w 1936 r. - 142, w 1937 r. - 171. Największa liczba sędziów śledczych przypadała na warszawski okręg apelacyjny, spora ich liczba była też w okręgach apelacyjnych: lubelskim i wileńskim, natomiast najmniejsza w krakowskim, poznańskim i toruńskim. Na przykład w 1930 r. na 231 sędziów śledczych w poszczególnych apelacjach było: w apelacji warszawskiej - 89 sędziów śledczych, w lubelskiej - 48, w wileńskiej - 46, we lwowskiej - 25, w katowickiej-11, w poznańskiej - 6, w toruńskiej - 4 i w krakowskiej - $2^{37}$.

Praktyka Ministerstwa Sprawiedliwości związana z powoływaniem do funkcji sędziów śledczych polegała na powierzaniu ich często osobom o małym doświadczeniu zawodowym, czasem nawet asesorom. Nie sprzyjało to wytworzeniu się właściwego stosunku między sędzią śledczym, prokuratorem i policją, czyli organami współdziałającymi w postępowaniu przygotowawczym. Młodzi, niedoświadczeni sędziowie często nie potrafili wzbudzić odpowiadającego ich randze autorytetu ${ }^{38}$.

W świetle kodeksu postępowania karnego z 1928 r. sędzia śledczy i sędzia do spraw wyjątkowego znaczenia mieli za zadanie przede wszystkim prowadzenie śledztwa. Pewne czynności były też dla nich przewidziane w trakcie prowadzonego przez prokuraturę lub policję dochodzenia. Wyjątkowo mogli być też - na mocy przepisów ustrojowych - powoływani do uzupełniania składu sądzącego, a więc do pełnienia odmiennej funkcji - orzekania.

Dochodzenie miało na celu wyjaśnienie, czy istotnie popełniono przestępstwo, kogo można o nie podejrzewać i czy jest dostateczna podstawa, by oskarżyciel mógł żądać wszczęcia postępowania sądowego (art. $243 \S 1$ kpk). Czynności sądowe w trakcie dochodzenia przeprowadzane były bądź przez sędziego śledczego, bądź sąd grodzki. Wybór właściwego podmiotu należał do prowadzącego dochodzenie, tj. do prokuratora lub policji. Czynności te obejmowały: przesłuchanie podejrzanego, przesłuchanie pod przysięgą świadka, gdy zachodziła obawa, że świadek nie będzie mógł się stawić na rozprawie głównej lub bez przysięgi nie powie prawdy, zbadanie stanu umysłowego po-

${ }^{36}$ A. Goldman, ,,Redukcja”..., s. 375.

${ }^{37}$ J. Szarycz, Sędziowie i sądy w Polsce w latach 1918-1988, Warszawa 1988, s. 22-23.

${ }^{38}$ S. Waltoś, Sędzia śledczy - rys historyczny, [w:] Konferencja. Nowy model postępowania przygotowawczego - sędzia śledczy. Warszawa, 22 marca 2010 r., Warszawa 2010, s. 19. 
dejrzanego oraz podjęcie czynności ustalającej ślady przestępstwa, gdy zachodziła obawa, że na rozprawie głównej bez odczytania protokołu tej czynności, ślady nie dałyby się odtworzyć (art. $251 \mathrm{kpk}$ ). Po nowelizacji kodeksu postępowania karnego, dokonanej w 1932 r., katalog tych czynności został rozszerzony, między innymi o przesłuchanie świadków pokrzywdzonego oraz osób, które zatrzymały lub sprowadziły podejrzanego, a także o przesłuchanie świadka zamieszkałego poza okręgiem sądu okręgowego ${ }^{39}$. Tak więc uprawnienia sędziego śledczego i sądu grodzkiego realizowane w dochodzeniu dotyczyły przede wszystkim zabezpieczenia w sposób procesowy dowodów dla sądu orzekającego. W nagłych przypadkach, tzn. gdy sędziego nie było na miejscu zdarzenia, a zwłoka groziłaby zanikiem śladów lub dowodów przestępstwa, możliwe było podjęcie niektórych z tych czynności sądowych przez prokuraturę lub policję. Nie należało do nich jednak badanie stanu psychicznego podejrzanego. To prawo zastępowania organów sądowych w czynnościach sądowych przez organy prokuratury lub policji było szczególnie krytykowane ${ }^{40}$.

Śledztwo było postępowaniem prowadzonym przez sędziego śledczego, sędziego śledczego do spraw wyjątkowego znaczenia lub - w sytuacji, gdy toczyło się poza siedzibą sądu okręgowego - sąd grodzki (art. $258 \mathrm{kpk}$ ). Było wszczynane tylko w sprawach należących w I instancji do właściwości sądu okręgowego, a jego celem było wszechstronne wyjaśnienie okoliczności sprawy i dostarczenie oskarżycielowi publicznemu niezbędnych informacji co do zasadności żądania wszczęcia postępowania sądowego lub umorzenia postępowania, a także utrwalenie dowodów dla sądu wyrokującego (art. 259 kpk). Wszczęcie śledztwa następowało na wniosek prokuratora lub na wniosek podejrzanego. W sytuacji, gdy sędzia śledczy nie zgadzał się z wnioskiem prokuratora, przedstawiał sprawę sądowi okręgowemu do rozstrzygnięcia, sam zaś podejmował jedynie czynności nie cierpiące zwłoki (art. 262 kpk). Kiedy jednak wniosek o wszczęcie śledztwa pochodził od podejrzanego, był on uprawniony do samodzielnego podjęcia decyzji bądź o wszczęciu śledztwa, bądź o oddaleniu wniosku. Wszelkie postanowienia sędziego śledczego i sądu okręgowego w przedmiocie wszczęcia śledztwa podlegały zaskarżeniu w drodze zażalenia (art. 262-264 kpk).

Sędzia był zobowiązany do natychmiastowego przesłuchania podejrzanego (chyba że był już wcześniej przesłuchiwany w trybie art. 168 kpk, na przykład przez innego sędziego śledczego, po doprowadzeniu go na skutek zatrzymania) i wydania w ciągu 24 godzin postanowienia o jego tymczasowym aresztowaniu (art. $265 \mathrm{kpk}$ ). W sytuacji, gdy podejrzany był już w areszcie, a sędzia stwierdził, że brakowało do tego podstaw, miał on obowiązek zwol-

39 Ustawa z dnia 21 stycznia 1932 r. zmieniająca niektóre przepisy postępowania karnego (Dz. U. 1932, Nr 10, poz. 60).

${ }^{40}$ Zob. A. Mogilnicki, Czynności sądowe w toku dochodzenia wedlug k.p.k. i projektu Komisji Kodyfikacyjnej, „Gazeta Sądowa Warszawska” 1929, Nr 49, s. 733-737. 
nić podejrzanego bezzwłocznie ${ }^{41}$. W trakcie śledztwa sędzia śledczy podejmował wszelkie czynności z własnej inicjatywy, między innymi: przesłuchiwał świadków pod przysięgą; badał okoliczności sprawy poprzez przesłuchiwanie świadków, biegłych, przeprowadzanie oględzin lub rewizji; rozstrzygał o przepadku kaucji lub o ściągnięciu sumy poręczenia; zezwalał stronom i ich obrońcom lub pełnomocnikom na przeglądanie akt i robienie uwierzytelnionych odpisów, choć strony miały prawo do składania mu wniosków. Samodzielność sędziego ograniczały prawne wnioski prokuratury, do których należały właściwie wszelkie wnioski przewidziane ustawą, na przykład wnioski: o przeprowadzenie czynności dowodowych, o zezwolenie na przeglądanie akt, o zaprzysiężenie świadków, o uchylenie lub złagodzenie środka zapobiegawczego i inne ${ }^{42}$. Prokurator miał prawo uczestniczyć przy wszystkich czynnościach śledczych, o obecności innych stron decydował sędzia śledczy (art. $268 \mathrm{kpk})$.

W przypadku, gdy sędzia śledczy stwierdził brak przesłanek do uznania, że dalsze prowadzenie śledztwa mogło dać podstawy do rozprawy głównej, zawiadamiał o tym oskarżyciela, nie miał jednak samodzielnych kompetencji do umorzenia postępowania (art. $271 \mathrm{kpk}$ ). Miał natomiast prawo do umorzenia śledztwa, gdy oskarżyciel posiłkowy lub prywatny tego żądał lub się na to zgadzał oraz na żądanie lub za zgodą prokuratora (art. 272 kpk). Później, po zmianach wprowadzonych w 1932 r., musiał obligatoryjnie umorzyć śledztwo, jeżeli zażądał tego prokurator. Uznawszy, że śledztwo dostarczyło już podstaw do rozprawy głównej, sędzia śledczy wydawał postanowienie o jego zamknięciu.

IV. Kodeks postępowania karnego od chwili wejścia w życie był wielokrotnie nowelizowany i zmiany te dotyczyły też instytucji sędziego śledczego. Kierunek zmian był jeden: zwiększenie uprawnień prokuratora kosztem uprawnień sędziego. W efekcie w śledztwie konkurowały ze sobą dwa podmioty: sędzia śledczy i prokurator, co wpływało na jego przebieg; opóźniając je i wydłużając niepotrzebnie, a czasem odbierając nawet faktyczny sens czynnościom sędziego śledczego. W praktyce bowiem prokurator, otrzymawszy zawiadomienie o przestępstwie, z reguły nie kierował sprawy bezpośrednio do sędziego śledczego, lecz przeprowadzał dochodzenie, którego celem było wyjaśnienie, czy popełniono przestępstwo, kogo można o nie podejrzewać oraz czy zachodzi podstawa do wszczęcia postępowania sądowego. Tak więc $\mathrm{w}$ zasadzie już $\mathrm{w}$ tym stadium postępowania, prokurator musiał rozstrzygnąć kwestię, czy istnieje podstawa do przypisywania konkretnej osobie

${ }^{41}$ Zob. E. Wiśniewski, Sporne kwestie z zakresu śledztwa, „Głos Sądownictwa” 1931, Nr 5, s. 276 .

${ }^{42}$ Zob. K. Eichstaedt, Rola sądu w postępowaniu przygotowawczym a instytucja sędziego śledczego, Warszawa 2009, s. 61. 
czynu karalnego. By móc to stwierdzić, prokurator miał do dyspozycji wiele możliwości prawnych, które w zasadzie były podobne do uprawnień sędziego śledczego w trakcie śledztwa ${ }^{43}$.

Praktyka prowadzonych śledztw była daleka od ideału. Sędziowie śledczy otrzymywali zbyt wiele spraw, a w efekcie niektóre długo czekały na podjęcie, co z kolei powodowało, że rezultaty takich przeciąganych czy odkładanych śledztw były nikłe. W dodatku młodzi i niedoświadczeni sędziowie lub asesorzy, często pełniący funkcję sędziów śledczych, nie stanowili gwarancji prawidłowego ich przebiegu. Brakowało im zarówno właściwego doświadczenia zawodowego, w tym szczególnych kwalifikacji do prowadzenia trudnych i zawiłych śledztw, ale nawet zwykłego doświadczenia życiowego, również bardzo przydatnego do wykonywania takich obowiązków ${ }^{44}$. Sędziowie śledczy byli tak mocno przeciążeni pracą, że wydawano nawet dla poszczególnych okręgów sądowych okólniki wzywające do zmniejszania w rewirach liczby śledztw ${ }^{45}$.

V. Dyskusja nad instytucją sędziego śledczego oraz modelem postępowania przygotowawczego rozgorzała $\mathrm{w}$ środowiskach prawniczych właściwie dopiero pod rządami zunifikowanego prawa. Wcześniej komentarzy na łamach prasy fachowej nie było zbyt wiele i dotyczyły one głównie interpretacji obowiązujących przepisów, nie zaś ich dogłębnej analizy. Wynikało to zapewne z uznania pozaborczego stanu prawnego za przejściowy i skupienia się na śledzeniu prac nad jednolitym prawem. Ostatecznie, przyjęte rozwiązania nie zadowoliły jednak właściwie nikogo: ani teoretyków prawa, ani praktyków - a wśród tych ostatnich zarówno sędziów, jak i prokuratorów - stąd szeroka, a od połowy lat trzydziestych coraz szersza fala ich krytyki.

Zasadniczą sprawą sporną w doktrynie międzywojennej była kwestia zasadności istnienia instytucji sędziego śledczego. Sporą liczbę zwolenników miała teoria uznająca zbędność tej instytucji w postępowaniu karnym. Być może głównym źródłem tego poglądu była jego niedoskonała forma prawna. Zwolennicy likwidacji instytucji sędziego śledczego postulowali przekazanie całego postępowania przygotowawczego w ręce prokuratora. Przemawiać miała za tym przede wszystkim zasada, że to prokurator bierze na siebie odpowiedzialność za postawienie konkretnej osoby w stan oskarżenia i w związku z tym powinien osobiście podejmować wszelkie czynności zmierzające do wyjaśnienia stanu faktycznego i prawnego sprawy. Tylko skupienie w jednym ręku tych wszystkich kompetencji może - dowodzono - gwaran-

${ }^{43}$ A. Eimer, O nowy ustrój Prokuratury, „Głos Sądownictwa” 1935, Nr 10, s. 710-711.

${ }^{44}$ S. Lipień, Czy sędzia śledczy jest jeszcze potrzebny?, „Głos Sądownictwa” 1936, Nr 2 , s. 135.

45 J. Wayzner, Przygotowawcze postępowanie karne w praktyce, „Głos Sądownictwa” 1935, Nr 6, s. 434. 
tować trafną ocenę okoliczności sprawy i zasadność ewentualnego oskarżenia. Prokurator sporządzający akt oskarżenia nie powinien zaznajamiać się ze sprawą jedynie na podstawie akt sporządzonych przez organy sądowe, lecz bezpośrednio poprzez swoje działania ${ }^{46}$. W tej sytuacji rola sądu miała się ograniczać wyłącznie do wyrokowania, a instytucja sędziego śledczego stawała się zbędna ${ }^{47}$. Ta koncepcja - jak podkreślano - miała ewidentne zalety: usunięcie szkodliwej konkurencji sędziego i prokuratora, zniesienie wadliwej instytucji śledztwa oraz zbliżenie prokuratora do społeczeństwa. Ten ostatni czynnik był szczególnie akcentowany, jako niezwykle ważny z punktu widzenia interesu społecznego. Proponowano nawet, by wyznaczać prokuratorom, posiadającym takie rozszerzone uprawnienia, miejsce urzędowania poza siedzibą urzędu prokuratorskiego, co miało przede wszystkim ułatwiać dostęp miejscowej ludności do prokuratora, a w efekcie prowadzić do powstania faktycznej łączności między nim a mieszkańcami. Postulowano przy tym wzrost zadań prokuratora związanych z prewencją ogólną.

Częsty był pogląd, że ustawodawca podzielił funkcje, które składały się na jedno postępowanie przygotowawcze, pomiędzy prokuratora i sędziego śledczego, gdyż był nieufnie nastawiony do jednego z tych podmiotów - do prokuratora i dążąc do ograniczenia jego kompetencji, przekazał wiele z nich sędziemu śledczemu. Podkreślano jednak, że w zakresie przygotowania zawodowego oraz wymogów etyki zawodowej, prawo o ustroju sądów powszechnych z 1928 r. nie czyniło właściwie żadnych większych różnic między przedstawicielami tych dwóch zawodów prawniczych, wymagając jednakowych studiów i tej samej aplikacji zawodowej, a nawet, pozwalając na w miarę swobodne przechodzenie od wykonywania jednego z tych zawodów do drugiego. Argumentując zaś przeciwko poglądowi uznającemu prokuratora za mniej bezstronnego niż sędzia, wskazywano, że działania prokuratora nie były nastawione wyłącznie na oskarżanie podejrzanego, gdyż jego rola nie kończy się z chwilą sporządzenia aktu oskarżenia, lecz trwa nadal podczas postępowania sądowego, kiedy jego twierdzenia przechodzą przez ocenę sądu i ocenę społeczną, o ile rozprawa toczy się bez wyłączenia jawności. Stwierdzano: „Żaden oskarżyciel publiczny nie ma interesu w tym, aby narażać się na ciężki zarzut, iż zniekształca rzeczywisty obraz wydarzeń, przy tym możność wysnuwania z nich jednostronnych wniosków jest nader ograniczona. Jak wyglądałby wobec społeczeństwa i władzy przełożonej stróż praw, któryby wniósł niesłuszne oskarżenie i przekręcił fakty?"48. Podnoszono nawet, że to właśnie podział czynności wchodzących w skład postępowania przygotowawczego bardziej sprzyja nieprawidłowościom niż ich przekazanie

${ }^{46}$ A. Eimer, Prokurator czy sędzia śledczy, „Głos Sądownictwa” 1936, Nr 5, s. 390-391.

${ }^{47}$ Idem, O nowy ustrój Prokuratury, „Głos Sądownictwa” 1935, Nr 10, s. 710-712.

${ }^{48} \mathrm{H}$. Chutkiewicz, Kto ma utrwalać materiaty dla procesu karnego?, „Głos Sądownictwa” 1936, Nr 5, s. 392. 
wyłącznie w ręce prokuratora. Nie do końca bowiem pozostaje rozstrzygnięta kwestia odpowiedzialności za przebieg i wynik postępowania przygotowawczego. Prokurator wnoszący na przykład bezzasadne oskarżenie może, przy zachowaniu obowiązującego modelu, przerzucać odpowiedzialność na sędziego śledczego, natomiast obarczony pełną odpowiedzialnością za całe postępowanie byłby bardziej zdeterminowany jak najlepiej wyjaśnić sprawę, bo jeśli „(...) nie będzie mógł przerzucić na innych odpowiedzialności za powolność, złe załatwianie lub paczenie sprawy, (...) postara się załatwiać sprawy szybko i dobrze" 49 .

Odzywały się jednak również głosy opowiadające się za utrzymaniem instytucji sędziego śledczego. Na ogół dostrzegano wówczas konieczność jej reformy, czasem - zasadniczej. Jako remedium na nieprawidłowości występujące w postępowaniu przygotowawczym, zwłaszcza w postaci przedłużających się śledztw, proponowano przede wszystkim wzmocnienie pozycji sędziego śledczego kosztem roli prokuratora, połączone z prowadzeniem bardziej prawidłowej polityki kadrowej w sądownictwie. Stanowiska sędziów śledczych miały być obsadzane nie jak dotąd młodymi prawnikami, lecz przeciwnie osobami o największym doświadczeniu i najwyższych umiejętnościach zawodowych. Ich pozycja w hierarchii sądowej miała być szczególnie wzmocniona, a przynajmniej w pełni i rzeczywiście zrównana z pozycją sędziów orzekających. Sędziowie ci mieli być wyposażeni we wszystkie niezbędne środki do prawidłowego i szybkiego działania, zaś ich dotychczasowe ograniczenia występujące przede wszystkim za sprawą prokuratora - zniesione. To sędzia miał samodzielnie decydować o kolejnych etapach śledztwa, łącznie $\mathrm{z}$ jego zakończeniem. Ciekawą propozycją był projekt utworzenia w sądach okręgowych wydziałów śledczych, na czele z osobnym lub wspólnym z wydziałem karnym wiceprezesem. Liczba sędziów śledczych miała być zależna od aktualnych, a zmieniających się przecież potrzeb, co oznaczało możliwość delegowania sędziów orzekających do śledztw i odwrotnie - sędziów śledczych do orzekania. Wydział śledczy miał prowadzić własną kancelarię, na czele z odrębnym sekretarzem. Wiceprezes miał uzyskać stały wgląd w racjonalny podział pracy w wydziale, natomiast sędziowie śledczy tak potrzebną platformę współpracy ${ }^{50}$.

Za utrzymaniem instytucji sędziego śledczego miał też przemawiać zakres i charakter czynności podejmowanych w trakcie postępowania przygotowawczego, trudny - zdaniem wielu - do zrealizowania wyłącznie przez prokuraturę, nawet wspomaganą przez organa policji. Podnoszono, że niektóre czynności wymagają szczególnej wiedzy i wnikliwości, charakteryzującej raczej sędziego niż inne organa biorące udział w tym postępowaniu: „istnieje

\footnotetext{
${ }^{49}$ Ibidem, s. 393.

${ }^{50}$ S. Lipień, Czy sędzia ..., „Głos Sądownictwa” 1936, Nr 2, s. 135-136.
} 
(...) wielka grupa spraw, gdzie zbierania materiałów w formie przesłuchiwania świadków, wyszukiwania i badania dowodów rzeczowych, absolutnie nie można powierzyć tak mało wykwalifikowanemu w tym względzie organowi, jakim jest policja państwowa" ${ }^{\text {1. }}$. Wprawdzie prokurator pod względem fachowym - jak twierdzono - jest w stanie czynności te wykonywać $\mathrm{z}$ równym powodzeniem co sędzia śledczy, jednak prowadzić miało to nieuchronnie do nadmiernego obciążenia go pracą, a w rezultacie - obniżenia efektów postępowania przygotowawczego. Podkreślano też, że charakter pracy sędziego śledczego, często monotonny i żmudny, oparty na ,metodycznym i powolnym badaniu różnych hipotez, z których jedna w końcu okaże się słuszną"52, jest czymś zupełnie innym niż „tocząca się wartką strugą, żywa i wieloraka”"53 praca prokuratora, polegająca na ocenie zebranego materiału pod kątem zasadności postawienia $\mathrm{w}$ stan oskarżenia oraz udziale $\mathrm{w}$ dalszych etapach postępowania sądowego. I choć - jak podkreślano - z punktu widzenia ekonomii wymiaru sprawiedliwości połączenie w jednym ręku funkcji prokuratora i sędziego śledczego, byłoby korzystne, to jednak już z punktu widzenia efektywności - nie. Dopiero funkcjonując osobno, pełniąc inne procesowe role, obydwa organy świetnie się wzajemnie uzupełniały.

Krytyce poddawano w końcu samą konstrukcję śledztwa, uznając ją za niespełniającą ważnych społecznych potrzeb. Najgorzej oceniano opóźniony moment jego wszczęcia oraz powolny przebieg. Uzależnienie wszczęcia śledztwa od wniosku prokuratora uznawano za jedną z przyczyn nieefektywności pracy śledczej sędziego, bo sprawa trafiała do niego nieraz za późno, by we właściwy sposób znaleźć i utrwalić dowody popełnionego przestępstwa, a działo się tak dlatego, że prokurator czekal ze złożeniem wniosku o wszczęcie śledztwa do momentu otrzymania z rąk organów policyjnych odpowiedniego materiału w postaci dochodzenia. Podkreślano, że śledztwo, poprzedzone takim dochodzeniem, w dużej mierze ogranicza się do ponawiania czynności, wcześniej już przeprowadzonych $\mathrm{w}$ trakcie dochodzenia, $\mathrm{z}$ tą jednak różnicą na niekorzyść śledztwa - że dokonywanych znacznie później, a więc nie „na gorąco". Pojawiały się w tej sprawie jednak też głosy, że jeśli sędzia śledczy „przerabia” tylko drugi raz materiał ustalony już w dochodzeniu, to oznacza, że po prostu albo niepotrzebnie wszczęto śledztwo, albo sędzia śledczy nieumiejętnie je prowadzi ${ }^{54}$. Postulowano takie ,przekonstruowanie" dochodzenia i śledztwa, żeby uzyskały szansę w jednakowym stopniu, ale bez powtarzania, realizować postawione przed nimi zadania: niezwłocznego zebrania i utrwalenia materiału dowodowego. Miało do tego prowadzić przede wszystkim umożliwienie sędziemu śledczemu zbierania materiału dowodowego na

\footnotetext{
${ }^{51}$ W. Strumieński, Sędzia śledczy czy prokurator, „Głos Sądownictwa” 1935, Nr 11, s. 785.

${ }^{52}$ Ibidem, s. 786.

${ }^{53}$ Ibidem.

${ }^{54}$ J.E. Grabowski, W obronie śledztwa, „Głos Sądownictwa” 1935, Nr 12, s. 871.
} 
miejscu przestępstwa bezpośrednio po jego popełnieniu i wszczynanie śledztwa niezależnie od wniosku prokuratorskiego. Jako praktyczne i uzasadnione rozwiązanie proponowano zespolenie z funkcją sędziego śledczego organów policyjnego wydziału śledczego. Wydział ten prowadziłby pod kierownictwem sędziego śledczego nie tylko poszczególne czynności śledcze, ale także dochodzenia w sprawach nieco mniejszej wagi niż sprawy wyjaśniane w toku śledztwa. Dochodzenia w sprawach najdrobniejszych pozostawiono by posterunkom i komisariatom policji państwowej. Podsumowując, stwierdzano, że: „tego rodzaju organizacja dochodzeń i śledztw niewątpliwie bardziej odpowiadałaby nowoczesnym sposobom walki z przestępcami i przestępstwem, dając jednocześnie maksimum pewności nienaruszania nietykalności osobistej, tej podwaliny wolności obywatelskiej, a w związku z reorganizacją instytucji sędziów śledczych i śledztwa jako takiego, wyłoniłaby się potrzeba częściowej również reorganizacji dotychczasowego ustroju tak prokuratur, jak i sądów powszechnych" 55 .

VI. Spróbujmy podsumować powyższe uwagi. Dyskusja o zasadności, a także zakresie funkcjonowania instytucji sędziego śledczego wpisywała się w kilka szerzej zakrojonych obszarów. Pierwszy z nich był związany z postulatem zreformowania, a zwłaszcza ujednolicenia postępowania przygotowawczego. Jak podkreślano, postępowanie to przybierało najrozmaitsze formy: dochodzenia nieformalnego tzw. zapiskowego robionego przez policję; dochodzenia formalnego tzw. prokuratorskiego; dochodzenia sądowego oraz śledztwa. Do tego dochodziły różne formy kombinowane, łączące nieraz różne typy w jednej sprawie. Wszystko to wpływało - zdaniem wielu - niekorzystnie na przebieg postępowania. Stąd powtarzający się postulat ujednolicenia tej fazy postępowania karnego ${ }^{56}$. Według często wyrażanego poglądu najbardziej niekorzystna dla wyników postępowania przygotowawczego była różnorodność podmiotów biorących w nim udział, w różnym zakresie i na różnych etapach. Tak więc skoncentrowanie całego postępowania przygotowawczego w jednym ręku i jednej podstawowej formie miało gwarantować ciągłość, sprawność i bezstronność przy ściganiu przestępców. Za najbardziej odpowiedni do tego organ uznawano najczęściej prokuratora. Tezie o konieczności skoncentrowania postępowania przygotowawczego w ręku prokuratora przeciwstawiano jednak wytrwale pogląd o możliwości, a nawet potrze-

55 J. Salewicz, Ustawowa konstrukcja śledztwa w praktyce, „Głos Sądownictwa” 1935, Nr 2, s. 103.

${ }^{56}$ E. Wiśniewski, Uwagi w sprawie reformy postępowania przygotowawczego karnego, „Głos Sądownictwa" 1936, Nr 1, s. 46-50; M. Hauswirt i S. Popower, Proponowane zmiany śledztwa $i$ dochodzenia $w$ świetle zasad procesowych, „Archiwum Kryminologiczne”, Tom I, z. 2, s. 255 i nast.; J. Kondratowicz, Czy potrzebna jest reforma postępowania przygotowawczego karnego, „Gazeta Sądowa Warszawska” 1935, Nr 17 i 18. 
bie współdziałania prokuratora i sędziego śledczego właśnie dla dobra tego postępowania. To dzięki temu współdziałaniu wykrycie prawdy materialnej - czyli osiągnięcie podstawowego celu postępowania - miało być łatwiejsze. „Czyż można twierdzić, że taka dyskusja dwóch czynników, występujących w śledztwie jest szkodliwa, niepotrzebna, że przeciwnie istnieje potrzeba jednolitości? Zapewne, doraźne efekty może łatwiej osiągnąć jeden człowiek, niż dwóch, ale przecież śledztwo dąży do wykrycia prawdy materialnej, do czego rozważenie danego zagadnienia z różnych punktów widzenia może być tylko korzystne" ${ }^{57}$.

Drugi ważny obszar dyskusji dotyczył efektywności, a właściwie w praktyce braku efektywności samego śledztwa. Często powtarzanej tezie o powolności śledztwa przeciwstawiano argumentację wskazującą przede wszystkim na zawiłość spraw będących jego przedmiotem, jak i konieczność osobistego wykonywania przez sędziego śledczego wszystkich niemal czynności. Pewnym doraźnym lekiem na to zjawisko miało być udoskonalenie pracy organów pomocniczych sędziego śledczego. Przede wszystkim jednak podnoszono, że zarzut powolności jest nieistotny, gdyż sprawy trudne i zawiłe - a przecież tylko w takich sprawach śledztwa były wszczynane - nie powinny być prowadzone pośpiesznie i niedokładnie ${ }^{58}$. Najczęściej winą za opóźnienie śledztwa obarczano procedury jego wszczęcia, uzależnione od wniosku prokuratora. Jednak i w tej kwestii pojawiały się głosy polemiczne. Stwierdzano, na przy$\mathrm{kład}$, że fakt, iż to prokurator wszczyna śledztwo niekoniecznie wpływa na opóźnienie tego postępowania, bo przecież jego wniosek mógł być zgłaszany w drodze telefonicznej, co zresztą dość często było praktykowane. Także policja, dowiedziawszy się o popełnieniu przestępstwa, mogła i zawiadamiała o tym prokuratora drogą telefoniczną, co znacznie przyśpieszało postępowanie. To, że sędzia śledczy czasem powtarzał niektóre czynności wykonane już w dochodzeniu, wynikało z faktu, że prokurator nieraz dopiero po przeprowadzeniu dochodzenia stwierdzał potrzebę przeprowadzenia śledztwa, a to usprawiedliwiało też pewną zwłokę w jego wszczęciu. Poza tym sędzia śledczy najczęściej miał jednak za zadanie wyjaśnienie takich okoliczności sprawy, które wymagały dokonania szeregu czynności sądowych, popartych wiedzą prawniczą, lecz niekoniecznie wymuszających wielki pośpiech, na przykład przeprowadzenie ekspertyz dowodów rzeczowych ${ }^{59}$.

W Europie poglądy na potrzebę funkcjonowania instytucji sędziego śledczego oraz śledztwa były biegunowo różne; od przekonania o niezbędności tych instytucji do twierdzenia o ich bezzasadności, a nawet szkodliwości. Nie brakło głosów, że są one zdobyczą cywilizacji prawniczej i wyrazem wyso-

\footnotetext{
${ }^{57}$ J.E. Grabowski, W obronie śledztwa, „Głos Sądownictwa” 1935, Nr 12, s. 870.

${ }^{58}$ Ibidem, s. 871.

${ }^{59}$ J. Wayzner, Przygotowawcze postępowanie..., „Głos Sądownictwa” 1935, Nr 6, s. 433-434.
} 
kiej kultury w prawodawstwie i wymiarze sprawiedliwości, gdyż gwarantują wolność osobistą oskarżonego i powagę wymiaru sprawiedliwości, zapobiegając wszczynaniu procesów nienależycie uzasadnionych. Podkreślano, że śledztwo jest niezbędnym czynnikiem przygotowawczym do sądzenia przestępstwa i przestępcy, a nawet, że jest „duszą procesu”, gdyż nadaje mu treść i formę, dostarcza środki do zdobycia prawdy, wywiera wpływ na przebieg procesu oraz na wyrokowanie, a równocześnie daje wszelkie zabezpieczenia niezbędne dla spełnienia posłannictwa sprawiedliwości. Podkreślano przy tym, że sędzia śledczy musi być znakomicie do swej niezwykle ważnej roli przygotowany, wszelkie bowiem błędy i zaniedbania z jego strony stanowią zagrożenie dla najważniejszych interesów obywateli. Nie brakowało też jednak głosów, że śledztwo to „zabytek” dawnego procesu, pociągający za sobą liczne ujemne konsekwencje: marnowanie czasu i środków, powstanie sztucznego podziału odpowiedzialności między prokuratorem a sędzią śledczym, pozbawienie rozprawy głównej samodzielności i świeżości, ograniczenie praw oskarżonego ${ }^{60}$. W Polsce - jak widać z powyżej przytoczonej dyskusji przeważały stanowiska pośrednie, nie odrzucające na ogół instytucji sędziego śledczego oraz samego śledztwa, lecz postulujące jego głęboką i sensowną zmianę, polegająca przede wszystkim na właściwszym wzajemnym usytuowaniu sędziego śledczego i prokuratora. Takim, w którym sędzia nie byłby pozbawiony swobody rozstrzygania, natomiast prokurator zmuszony do narzucania mu określonych czynności ${ }^{61}$.

Wiele $\mathrm{z}$ argumentów pojawiających się $\mathrm{w}$ tej międzywojennej polemice na temat zasadności, ale i kształtu instytucji sędziego śledczego, wyrażanych jest i dzisiaj ${ }^{62}$. Szereg wątpliwości rodzących się w ciągu stulecia pozostaje do dziś aktualnymi, a zatem nierozwiązanymi zadowalająco. Współczesna dyskusja na temat instytucji sędziego śledczego toczy się jednak bardziej wokół modelu postępowania karnego, zwłaszcza jego fazy przygotowawczej, niż samej problematyki sędziego śledczego. Dopiero odpowiedzi na pytania o to, jak ma wyglądać postępowanie przygotowawcze oraz relacja między postępowaniem przygotowawczym a sądowym, mogą pozwolić na formułowanie dalszych konkluzji dotyczących między innymi instytucji sędziego śledczego, a więc: czy w tym postępowaniu jest dla niej miejsce, a jeśli tak, to jakie?

${ }^{60}$ W. Nestorowicz, Różne poglądy na potrzebę śledztwa, „Głos Sądownictwa” 1933, Nr 5, s. 13-17.

${ }^{61}$ J.E. Grabowski, W obronie śledztwa, „Głos Sądownictwa” 1935, Nr 12, s. 871.

${ }^{62}$ Zob. Konferencja. Nowy model postępowania przygotowawczego - sędzia śledczy. Warszawa, 22 marca 2010 r., Warszawa 2010. 


\title{
THE INSTITUTION OF AN INVESTIGATING JUDGE IN POLAND \\ IN THE INTER-WAR PERIOD (1918-1939)
}

\author{
Summary
}

The institution of an investigating judge emerged in all three parts of then partitioned Poland at almost the same time, i.e. in the 70s of the 19th century, as the Austrians introduced it in 1873, the Russians in 1876, and the Germans in 1877. The very idea of an investigating judge and its model, however, derives from the legal system of Napoleonic France.

During the period between two World Wars, the institution of an investigating judge functioned first, as part of the legislation inherited from the occupant's legal system, and then as part of the Polish legal system resulting, mainly, from the implementation of the ordinance on the regime of common courts of law of 1928 and the code of criminal procedure of the same year. The function of an investing judge was for and foremost connected with the preliminary stage of criminal proceedings, and the investigation process in particular. However, the main overall task of that stage was protection of an individual's rights in a criminal proceeding.

In the twenty years' history of the interwar Poland, the role of an investigating judge in a criminal proceeding had been gradually limited, while the prosecutor's role had increasingly strengthened. Although the prosecutor's supervision sensu stricto was formally non-existent, a prosecutor could, in many cases, restrict a judge's independence by issuing binding conclusions. Such practice was further facilitated by the fact that the Ministry of Justice's policy was to recruit for the position of an investigating judge from among the least experienced, usually junior judges.

Thus the institution of an investigating judge was subsequently subjected to strong criticism by many lawyers, both theorists as well as practitioners of a criminal trial. Its supporters criticised the influence that procurators could exercise on the judges and demanded their independence of the former, whereas its critics questioned the very sense or idea of an investigating judge, emphasising that it only constituted an interim form between a prosecuting organ and an independent court and, as such, performed neither of those two had functions sufficiently satisfactory.

\section{INSTITUTION DU JUGE D'INSTRUCTION EN POLOGNE PENDANT L'ENTRE-DEUX-GUERRES}

\author{
Resume
}

L'institution du juge d'instruction apparaît au XIX ${ }^{\mathrm{e}}$ siècle qusiment au même moment sur l'ensemble des territoires annexés par les trois voisins de Pologne. Le législateur autrichien introduit cette fonction au sein de l'institution judiciaire en 1873, 
le législateur russe en 1876 et l'allemand en 1877. L'idée même cependant ainsi que le modèle du régime trouvent son origine dans le système juridique de la France napoléonienne. Durant la période de l'entre-deux-gueurres, l'institution du juge d'instruction peut fonctionner tout d'abord sur la base de l'ensemble des textes de lois et règlements instaurés après le partage du pays, ensuite, en vertu de la législation polonaise, notamment le règlement concernant le régime des tribunaux de droit commun de 1928 ainsi que le code de procédure pénale promulgué la même année. Le rôle que joue à l'époque le juge d'instruction est en rapport avec l'étape de préparation de la procédure pénale, et notamment, l'enquête menée. Dans le cadre de cette dernière, le juge dispose de nombreux droits procéduraux particuliers mais sa mission globale et principale consite en la protection des droits de l'individu dans la procédure pénale. Pendant vingt ans d'existence de la $2^{\mathrm{e}}$ République, le rôle du juge d'instruction dans un procès pénal devient progressivement limité pour que, parallèlement, puisse prendre de l'ampleur la fonction du procureur. Il est vrai que formellement la surveillance de procureur n'existe pas au sens strict du terme, cependant dans beaucoup d'affaires le procureur avec ses demandes impératives aura quand même la possibilité de limiter l'indépendance du juge. Cette pratique est possible en outre grâce à la politique du personnel menée par le ministère de justice, celle-ci permettant aux personnes ayant peu d'expérience professionnelle, assesseur notamment, de postuler au poste de juge d'instruction. L'institution de juge d'instruction devient pendant l'entre-deux-guerres un objet de critiques faites par différents milieux des juristes, théoriciens et praticiens mais aussi par des praticiens de la procédure pénale. Ses partisans, mécontents de la forme de l'institution, revendiquent son indépendance du parquet. Ses ennemis par contre, contestateurs du sens de son existence, soulignent qu'elle constitue une forme intermédiaire entre l'organe de poursuite et un tribunal indépendant, par conséquent, elle ne pourrait remplir aucune de ces fonctions divergeantes de manière satisfaisante. 